\title{
The Effect of Stocking Temperature on Biodegradable Plastic Characteristics of Suweg Tuber (Amorphophallus campanulatus) with Addition of Glycerol and CMC (Carboxy Methyl Cellulose)
}

\author{
Layung Sari, Ulia Fitrass" ${ }^{*}$ Endaruji Sedyadi, Irwan Nugraha, Didik Krisdiyanto \\ Department of Chemistry, Faculty of Science and Technology, UIN Sunan Kalijaga \\ Jl. Marsda Adisucipto No 1 Yogyakarta 55281, Indonesia. Tel. +62-274-540971, Fax. +62-274-519739 \\ *Email: ulia.fitrass@gmail.com
}

\begin{abstract}
Research that uses Suweg tubers as the basic material for making biodegradable plastics has been carried out.. This research aims to determine the effect of stirring temperature on the characteristics of biodegradable plastic. Suweg tuber starch preparation is done as the manufacture of biodegradable plastic. Manufacture of biodegradable plastics made by mixing suweg tuber starch, glycerol, and acetic acid, as well as the CMC (Carboxy Methyl Cellulose). The manufacture of biodegradable plastic is carried out in two stages, namely stirring temperature variations $\left(80^{\circ} \mathrm{C}, 85^{\circ} \mathrm{C}, 90^{\circ} \mathrm{C}\right.$, and $\left.95^{\circ} \mathrm{C}\right)$ and the addition of CMC (Carboxy Methyl Cellulose). Tests carried out include FTIR test, mechanical test and biodegradation test. FTIR test is carried out to determine the functional groups contained in plasticThe test of plastic mechanical properties was carried out to determine the mechanical properties of plastics, such as tensile strength, elongation, and thickness. Biodegradation tests are carried out on the ground to determine the level of plastic degradation while in the environment. The results showed that the effect of temperature affected the mechanical properties of biodegradable plastic produced. Mechanical tests of stirring temperature variations with the addition of glycerol resulted in tensile strength, elongation, and thickness values of $80^{\circ} \mathrm{C}$ at $10.43 \mathrm{MPa} ; 2.08 \% ; 85^{\circ} \mathrm{C}$ at $28.52 \mathrm{MPa} ; 1.60 \%, 90^{\circ} \mathrm{C}$ of $29.76 \mathrm{MPa} ; 2.18 \%$, and $95^{\circ} \mathrm{C}$ of $32.49 \mathrm{MPa} ; 2.05 \%$. These results can be seen that the largest biodegradable plastic tensile strength is found in temperature variations of $95^{\circ} \mathrm{C}$, with a tensile strength of $32.49 \mathrm{MPa}$ elongation $2.05 \%$, and a thickness of $0.12 \mathrm{~mm}$.. Mechanical properties test of temperature variation with the addition of glycerol and CMC resulted in the value of tensile strength, elongation, and temperature thickness of $80^{\circ} \mathrm{C}$ at $18.68 \mathrm{Mpa} ; 12.22 \%, 85^{\circ} \mathrm{C}$ equal to $14.69 \mathrm{MPa} ; 9.16 \%, 90^{\circ} \mathrm{C}$ of $16.71 \mathrm{MPa} ; 14.72 \%, 95^{\circ} \mathrm{C}$ of $13.94 \mathrm{MPa} ; 14.166 \%$. These results can be seen that the largest biodegradable plastic tensile strength is found at $80^{\circ} \mathrm{C}$ temperature variations of $18.68 \mathrm{MPa}, 12.22 \%$ elongation, $0.14 \mathrm{~mm}$ thickness. FTIR test, the biodegradable plastic produced, it is known that the plastic group produced is like $\mathrm{CH}$, ester or ether. Plastic biodegradation test on soil, plastic with a temperature variation of $95^{\circ} \mathrm{C}$ has been degraded after 8 days, while plastic with the addition of CMC is degraded faster, for 7 days.
\end{abstract}

Keywords: Amorpophallus compactus, Biodegradable plastic, Cmc

\section{INTRODUCTION}

Plastics made from synthetic, hard outlined by the environment, and requires a long time, so the potential to pollute the environment. One alternative solution is through the development of biodegradable plastics, using thermoplastic starch (Saputra et al, 2015). There are two main raw materials that can be used in the manufacture of biodegradable plastics, namely products from animals (chitosan) and plant products (starch and cellulose).

Biodegradable plastic is plastic that can be used like conventional plastic, but it can be destroyed by microorganism activity in the environment to produce water and carbon dioxide gas (Sedyadi et al., 2016).

Plastic is formed from the polymerization process. Plastic explanation is defined as material in which the main ingredient is polymerized organic molecules with high molecular weights. The end product is solid, and in some parts the production stage can be shaped as desired (Akbar et al., 2013).
Polymers are a long series of repetitive sequences of small and simple molecules. This small molecule is called a monomer. Polymers are found in nature, both plants and animals. Polymers in nature such as starch, cellulose, chitosan, protein (Oktaviana, 2002).

The material used as a source of starch is the Suweg tuber (Amorphophallus campanulatus). Temperature variations used are between $80^{\circ} \mathrm{C}$ to $95^{\circ} \mathrm{C}$ at intervals of $5^{\circ} \mathrm{C}$. Plasticizer used in the formation of plastic is glycerol. Additional ingredients added to the manufacture of plastics are CMC (Carboxy Methyl Cellulose). Tests carried out are mechanical properties (thickness, tensile strength, and elongation), and plastic biodegradation tests on the soil. Statement of problem: How to manufacture bioplastic from Suweg tubers (Amorphophallus campanulatus) with the addition of plasticizers glycerol and CMC (Carboxy Methyl Cellulose)? What is the effect of temperature variations on the mechanical properties of bioplastics produced? What is the level of plastic degradation in the environment?

The purpose of this research are: To find out the manufacture of bioplastics from Suweg tuber with 
the addition of glycerol plasticizers and CMC (Carboxy Methyl Cellulose), to determine the effect of temperature variations on the mechanical properties of biodegradable plastic produced, to determine the level of plastic degradation in the environment.

\section{MATERIALS AND METHODS}

This research was conducted in several s tages. Stages of sample preparation, biodegradable plastic manufacturing and biodegradation test. The equipment used in this study included standard sieves, $100^{\circ} \mathrm{C}$ temometers, dexicators, pipettes, watch glasses, knives, basins, distilled water bottles, magnetic stirrers, $250 \mathrm{ml}$ beker cups, 100 $\mathrm{ml}$ beker glasses, scrapers, deaf spoons, sepatula and glass plates. Other equipment is the oven (Haraeus UT 6120), hot plate (CIMAREC), analytical balance (Ohaus Adventurer \pm 0.0001 gram). Sample analysis was carried out using Forier-Transform Infrared Spectroscopy and micrometer scrubs, tensile strength and elongation tester.

The materials will be used in this study are Suweg tuber starch (Amorphophallus campanulatus), aquades, acetic acid p.a., glycerol merck p.a., CMC (Carboxy Methyl Cellulose) blanos p.a. The work method of the research is: extraction of suweg tuber starch with precipitated, Biodegradable Plastic Manufacture by mixing Starch, Glycerol, Acetic Acid. Salt and Water. Stirring Temperature Variations without the addition of CMC (Carboxy Methyl Cellulose) and with the addition of CMC. Biodegradable Plastic Analysis by testing the mechanical properties and biodegradation tests and analysis of the Function Group with FTIR.

\section{RESULT AND DISCUSSION}

\section{Starch Extraction Process}

This simple starch extraction process, produces starch in the form of fine powder, white and not hygroscopic. The resulting Suweg tuber starch was analyzed using FTIR to determine the functional groups contained in the starch.

Absorption in the wave number area 2557.42 $\mathrm{cm}-1$, shows the presence of $\mathrm{OH}$ functional groups of carboxylic acids. CMC spectrum absorption in the area of $1585.37 \mathrm{~cm}-1$ indicates the presence of $\mathrm{C}=\mathrm{O}$ (carbonyl) groups, in the area of 1026.05 $\mathrm{cm}-1 ; 1053.06 \mathrm{~cm}-1 ; 1099.34 \mathrm{~cm}-1$; and 1269.07 $\mathrm{cm}-1$ shows the presence of functional groups of ethers and esters.

The manufacture of biodegradable plastics begins with variations in stirring temperature. This variation is done to find out the right temperature in making biodegradable plastic so that the best tensile strength is obtained. The reaction that occurs between starch and glycerol can be seen in Figure 1.

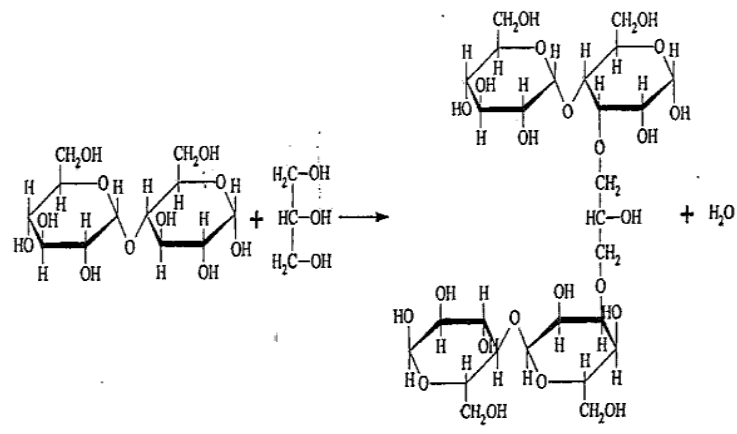

Figure 1. Reaction of starch and glycerol.

Addition of acetic acid serves as a terminator or reaction breaker in polymerization. The termination reaction aims to break some glycosidic bonds in starch into shorter starch molecules (Kusnandar, 2010 in Apriyanti, 2014). The reaction that occurs between starch and acetic acid, can be seen in Figure 2.

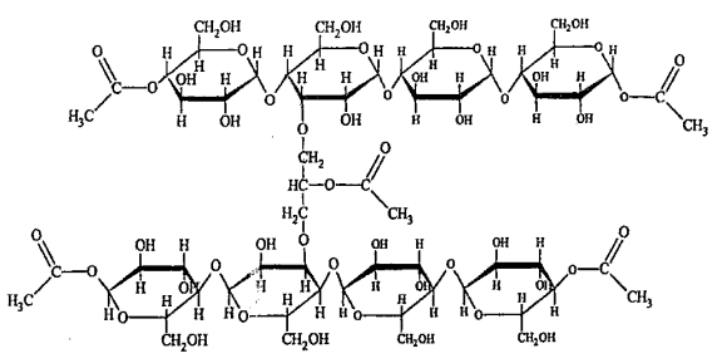

Figure 2. The reaction that occurs between starch and acetic acid.

The right amount of acetic acid is added to make the solution gel-shaped so it is more homogeneous. Excessive administration will inhibit gelatinization time, making the solution more watery and difficult to print. This is in accordance with the opinion expressed by Wuzburg, 1995 in Utomo, 2013. Modified starch with vinegar has hot paste viscosity, cold starch paste viscosity ratio, and lower gelatinization granule development. The addition of vinegar will increase the stability of starch or paste in warm water below the gelatinization temperature.

\section{Characterization of Biodegradable Plastics}

Characterization of biodegradable plastic, carried out on each plastic that is, biodegradable plastic with variations in stirring temperature and biodegradable plastic with the addition of CMC.

Factors that influence the mechanical test are the addition of starch, glycerol, and acetic acid. Addition of starch will make the plastic have a high tensile strength value. Addition of glycerol will 
affect the value of elongation. The addition of acetic acid will affect the viscosity and viscosity of the solution and the thickness of the plastic.

\section{Thickness}

Thickness is one of the parameters that affect the use of plastic for the products it packs. The lowest tensile strength values were produced on biodegradable plastic at $80^{\circ} \mathrm{C}$ stirring temperature. Biodegradble plastic at a stirring temperature of $80^{\circ} \mathrm{C}$, has a small tensile strength because, at lower temperatures there is an inequality of the distribution of starch components into the water. The elongation value is presented in Figure 3. Results of figure 3. showed that biodegradable plastic.

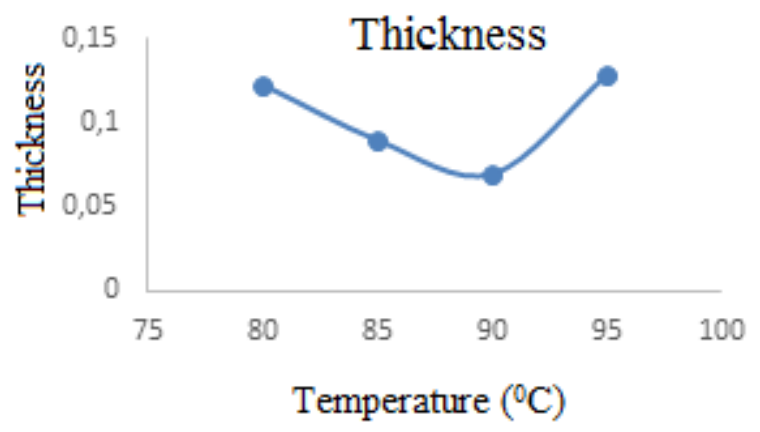

Figure 3. Plastic thickness with stirring variations.

Thickness decreased with increasing stirring temperature and increased at $95^{\circ} \mathrm{C}$. This is caused by different treatment factors, namely the lack of spreading when printing biodegradable plastic solutions.

\section{Tensile Strength}

Tensile Strength is one of the tests carried out to determine the strength of the plastic in receiving the load. High tensile strength values, it can be interpreted that the plastic gets stronger in receiving the load. High tensile strength values, can be influenced by the amount of starch used. Increased levels of amylose in solution can increase the number of hydrogen bonds formed. Figure 4 shows the value of tensile strength of eachz.

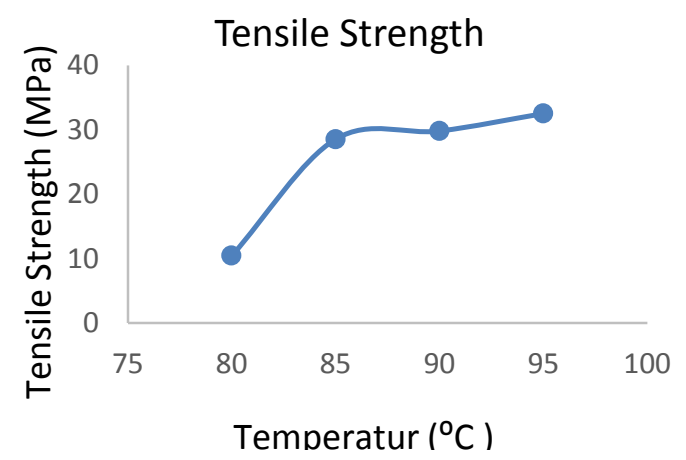

Figure 4. Plastic tensile strength with stirring temperature variations.

Temperature. Stirring temperature will affect the gelatinization process of a starch in solution. In figure 6 . It can be seen that the best tensile strength value is produced on biodegradable plastic with a stirring temperature of $95^{\circ} \mathrm{C}$. The lowest tensile strength value was produced on biodegradable plastic at $80^{\circ} \mathrm{C}$ temperature stirring. Biodegradable plastic at a stirring temperature of $80^{\circ} \mathrm{C}$, has a small tensile strength because, at lower temperatures there is an inequality of the distribution of starch components into the water.

\section{Elongasi}

Elongation is a test conducted to determine the ability of a plastic to stretch after being given a load. The higher the elongation value, the higher the ability of plastic to stretch. This study used the same ingredients and amounts of starch, glycerol and acetic acid. The results of the \% elongation value of biodegradable plastic can be seen in figure 5 .

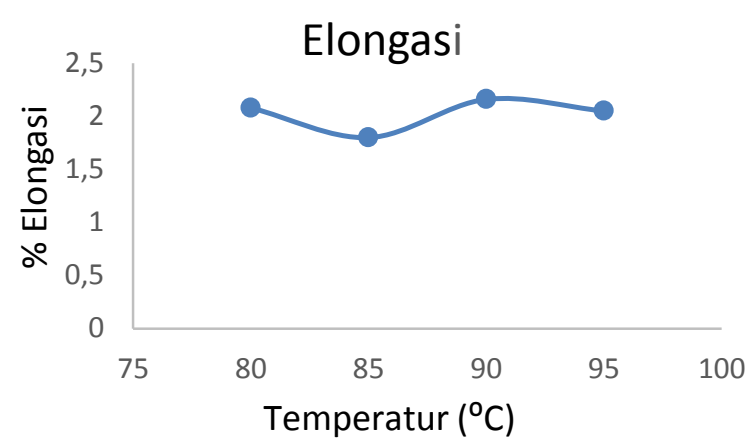

Figure 5. Elongation of biodegradable plastic with stirring temperature variations.

\section{Biodegradable Plastic Biodegradation Test}

Biodegradation test is carried out to determine the level of plastic breakdown when in the environment. The plastic that has been made, uses the basic ingredients of starch or which comes from nature, so that the synthetic plastic is a plastic that is boidegradable. The environment naturally has microorganisms that can decompose biodegradable plastic.

Testing of mechanical properties shows that the best biodegradable plastic is applied to a temperature of $95^{\circ} \mathrm{C}$. Based on figure 6 . shows a decrease in the mass of each plastic with variations in stirring temperature. This decrease in mass occurs because starch-based plastics can be degraded by microorganisms into their monomers (Feris et al., 2004).

The decline occurred very significantly at $90^{\circ} \mathrm{C}$ on day 0 and 2. Wirawan (2012) said that plastic added 
with glycerol plasticizer will degrade faster than plastic that does not use plasticizers.

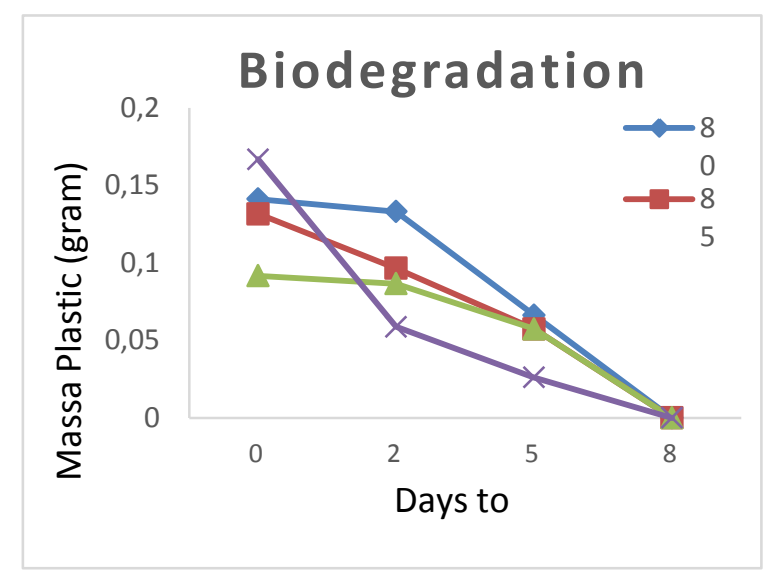

Figure 6. Graph of the decrease in biodegradable plastic mass with the effect of stirring temperature.

Addition of glycerol plasticizers will add to the hydrophilic nature of the plastic. This hydrophilic property will cause the plastic to absorb water more easily. Moist plastic will be easier to degrade by microorganisms in the environment.

\section{Best Biodegradable Plastic FTIR Test}

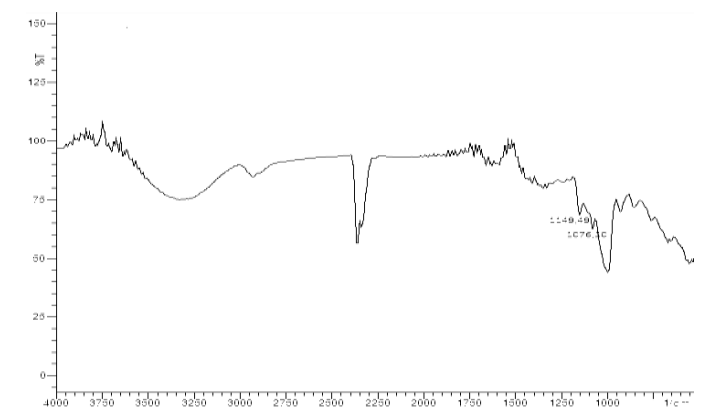

Figure 7. Best biodegradable Plastic FITR test.

Figure 7 is the result of the best plastic FTIR. The results obtained from the best biodegradable plastic shows the absorption at wave numbers 1149.49 $\mathrm{cm}-1$ and $1076.20 \mathrm{~cm}-1$ which indicate the presence of $\mathrm{C}-\mathrm{O}$ ether groups. On biodegrable plastics, only a small amount of absorption (detected) is seen, this is due to the weak energy in the function group in vibrating.

Characterization of Mechanical Properties of Biodegradable Plastics with Addition of CMC (Carboxy Methyl Cellulose)

Thickness is one of the parameters in the plastic mechanical test, because thickness can affect the material to be packaged. Thickness can affect the rate of steam transmission, as well as the mechanical properties of plastics such as tensile strength and elongation. Thickness is affected by solids dissolved in the solution before printing. Kamal (2010).

This study used the same amount of raw materials as starch, glycerol, and acetic acid, as well as the addition of CMC. The resulting thickness varies, although it has no significant effect. The thickness value generated in this study can be seen in Figure 8 .

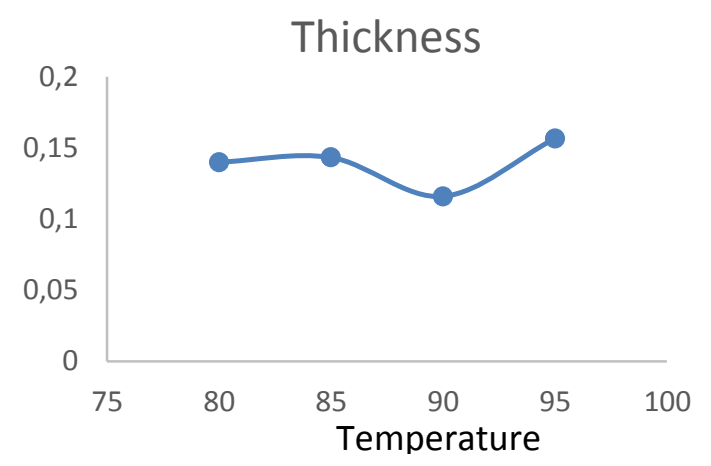

Figure 8. Thickness of plastic with stirring temperature variations and addition of CMC.

\section{Tensile Strength}

In Figure 8. shows that the stirring temperature variation does not have a significant effect on thickness. The thickness resulting from each stirring temperature variation is $80,85,90$, and $95^{\circ} \mathrm{C}$ which is $0.14 \mathrm{~mm}, 1.14 \mathrm{~mm}, 0.11 \mathrm{~mm}$, and $0.15 \mathrm{~mm}$. Based on the thickness value, it can be seen that the addition of CMC can increase thickness.

Variation in stirring temperature with the addition of CMC (Carboxy Methyl Cellulose) was carried out at temperatures of 80 to $95^{\circ} \mathrm{C}$. Based on the synthesis process it is known that the addition of CMC (Carboxy Methyl Cellulose) in solution can form a liquid with a stable and homogeneous viscosity.

The tensile strength value resulting from the stirring temperature variations with the addition of CMC (Carboxy Methyl Cellulose) can be seen in Figure 8 . The best tensile strength values obtained were $18.68 \mathrm{MPa}$ obtained at 80adukanC stirring temperature. The lowest tensile strength value of 13.94 MPa is at a stirring temperature of $95^{\circ} \mathrm{C}$.

The effect of stirring temperature on the mechanical properties of plastic. The tensile strength values obtained in the stirring temperature variations were $18.68,14.69,16.71$, and 13.94 $\mathrm{MPa}$, at a stirring temperature of $80,85,90$, and $95^{\circ} \mathrm{C}$. Based on figure 12 . the value of the best tensile strength is at a temperature of $80^{\circ} \mathrm{C}$. This shows that at a temperature of $80^{\circ} \mathrm{C}$ the starch of the Norwegian tuber has been gelatinized and at that temperature the mixture of ingredients in the manufacture of plastics has been homogeneous. At 
a temperature of $85^{\circ} \mathrm{C}$, the tensile strength decreased. Due to the increase in temperature which causes polysaccharides that experience excessive swelling. At higher temperatures there is an increase in deformability which will reduce mechanical properties due to higher swelling degree in polysaccharide granules (Dani \& Mawarani, 2012). At a temperature of $90^{\circ} \mathrm{C}$ the value of tensile strength increased and at a temperature of $95^{\circ} \mathrm{C}$ decreased again. The tensile strength value at a temperature of $95^{\circ} \mathrm{C}$ is not much different from the temperature of $85^{\circ} \mathrm{C}$, due to the increase in temperature, the polysaccharide will experience excessive swelling. At higher temperatures there is an increase in deformability which will reduce the mechanical properties due to higher swelling degree in polysaccharide granules (Dani \& Mawarani, 2012), only me in different temperature conditions.

\section{Elongation}

Elongation is a test conducted to determine the ability of a plastic to stretch after being given a load. The high value of elongation is influenced by the plasticizer added to the plastic solution. This study used the same ingredients and quantities as starch, glycerol, acetic acid, and CMC.

The elongation value of each temperature variation is $12.22 \%, 9.16 \%, 14.72 \%$, and $14.16 \%$, at a temperature variation of $80^{\circ} \mathrm{C}$, to $95^{\circ} \mathrm{C}$. The increase in elongation value after the addition of $\mathrm{CMC}$ is caused by CMC can maintain a stable and homogeneous solubility or viscosity, so that the glycerol can be dispersed perfectly.

\section{Biodegradation Test}

In figure 8 . it is known that biodegradation of biodegradable plastics with the addition of CMC occurs faster than biodegradable plastics without the addition of CMC.

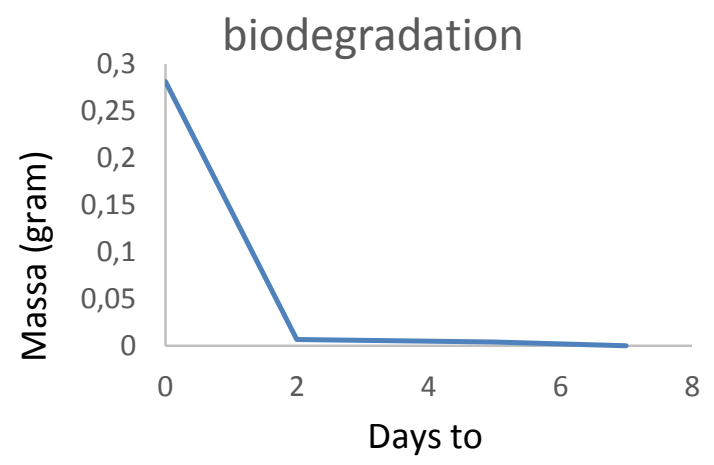

Figure 9. Biodegradation of plastic.

\section{Best Biodegradable FTIR Plastic Test with CMC Addition}

Characterization of biodegradable plastic is carried out using FTIR. Analysis using FTIR aims to determine the functional groups contained in biodegradable plastic. Biodegradable plastic with the addition of CMC peak appearance in the wave number area $2916.26 \mathrm{~cm}-1$, which indicates the presence of $\mathrm{CH}$ group, uptake 1461.94 indicates the presence of $\mathrm{CH} 2$ groups. At wave numbers 1014, $48 \mathrm{~cm}-1, \quad 1076.20 \mathrm{~cm}-1,1103.20 \mathrm{~cm}-1$, and $1149.49 \mathrm{~cm}-1$ indicate the presence of $\mathrm{C}-\mathrm{O}$ ether. Based on the picture above, the spectrum of biodegradable plastic with the addition of CMC shows that there are $\mathrm{CH}, \mathrm{CH} 2$ and $\mathrm{CO}$.

\section{CONCLUSIONS}

Making biodegradable plastic is done by mixing starch, glycerol, acetic acid and water, then heated, printed and oven. The best biodegradable plastic composition, is used as the next composition that will be added to the $\mathrm{CMC}$ to add tensile strength. Biodegradable plastic with variations in stirring temperature can affect the mechanical properties produced. Biodegradable plastic which has the best mechanical properties is achieved with a stirring temperature of $95^{\circ} \mathrm{C}$ with a tensile strength of $32.49 \mathrm{MPa}$, elongation of $2.05 \%$, and a thickness of $0.12 \mathrm{~mm}$, while the stirring temperature variation with the addition of CMC obtained the best mechanical properties of tensile strength 18, $68 \mathrm{MPa}$ elongation $12.22 \%$ and thickness of $0.14 \mathrm{~mm}$. Biodegradable plastic produced from each stirring temperature variation is biodegradable, ie it can decompose in the environment for 8 days, while biodegradable plastic with temperature variations with the addition of CMC decomposes faster when in the environment for 7 days.

\section{REFERENCES}

Afrozi, A. Sintesis dan Karakterisasi Katalis Nanokomposit Berbasis Titania untuk Produksi Hidrogen dari Gliserol dan Air. Jurnal Kimia. 2010. Depok : Departemen Teknik Kimia Universitas Indonesia.

Akbar, F.; Anita, Z.; \& Harahap, H. Pengaaruh Waktu SiMpan Film Plastik Biodegradasi dari Pati Kulit Singkong Terhadap Sifat Mekaniknya. Jurnal Teknik Kimia USU. 2013, Vol. 2, No. 2

Apriyani, Merry. Sintesis dan Karakterisasi Plastik Biodegradable dari Pati Ongok Singkong dan Ekstrak Lidah Buaya (Aloe Vera) dengan Plasticizer Gliserol. Skripsi, Universitas Islam Negri Sunan Kalijaga Yogyakarta, 2014

Cowd, M. A. Kimia Polimer. ITB Bandung: Bandung, 1991

Dawam. Kandungan Pati Umbi Suweg (Amorphophallus campanulatus) pada Berbagai Kondisi Tanah di Daerah Kalioso, Matesih dan Baturetno. Thesis, Universitas Negri Solo, Program Studi Biosains, 2010

Darni, Y.; Utami, H.; \& Asriah, d. N. 2009. Peningkatan Hidrofobisitas dan Sifat Fisik Plastik Biodegradable Pati Tapioka dengan Penambahan Selulosa Residu Rumput Laut Euchema spinossum. Seminar Hasil Penelitian \& Pengabdian Kepada Masyarakat. 
Firdaus, Feris.; \& Chairil Anwar. Potensi Limbah Padat-cair Industri Tepung Tapioka sebagai Bahan Baku Film Plastik Biodegradable. Jurnal Logika. 2004, Vol. 1, No. 2

Handayani, P. A.; \& Hesmita, Wijayanti. Pembuatan Film Plastik Biodegradable Dari Limbah Biji Duren (Durio zibethinus Murr.). Jurnal Bahan Alam Terbarukan. 2015, Vol 4, Edisi 1

Hidayat, M. Koirul.; Latifah.; \& Sedyawati, Sri M. R. Penggunaan Carboxy Methyl Cellulose Dan Gliserol Pada Pembuatan Plastik Biodegradable. Indonesian Journal of Chemical Science. 2013 Sci 2.

Ibrahim, H. S.; \& Sitorus, M. Teknik Laboratorium Kimia Organik, Graha Ilmu: Yogyakarta, 2013.

Julianti, E.; \& Mimi, N. Buku Ajar Teknologi Pengemasan, Fakultas Pertanian Universitas Sumatra: Utara Sumatra Utara, 2006

Kamal, Netty. Pengaruh Penambahan Aditif CMC (carboxyl Methyl Cellulose) Terhadap Beberapa Parameter Pada Larutan Sukrosa. Jurnal Teknologi. 2010, Vol. I, Edisi 17,

Kholish, Ach. Pemanfaatan Ongok Singkong sebagai Plastik Ramah Lingkungan dengan Plasticizer Gliserol. Skripsi, Universitas Islam Negri Sunan Kalijaga Yogyakarta, Jurusan Kimia, 2012.

Kusnandar, F. Kimia Pangan : Komponen Makro, Dyan Rakyat: Jakarta, 2010

Marhamah. 2008. Biodegradasi Plastik Poligliserol Asetat (PGA) dan Dioktil Ftalat (DOP) dalam Matriks Polivinil Klorida (PCV)dan Toksisitasnya Terhadap Pertumbuhan Mikroba. Medan: Universitas Sumatra Selatan.

Pradipta, I Made D.; \& Lizda Johar M. Pembuatan dan Karakterisasi Polimer Ramah Lingkungan Berbahan Dasar Glukomanan Umbi Porang. Jurnal Sains Dan Seni Pomits. 2012, Vol. 1, No. 1

Mu'azizah, Q. Perbandingan Karakter Tanaman Suweg (Amorphophallus campanulatus BI.) di Kecamatan Pangkur, Kabupaten Ngawi, Jawa Timur dan Kecamatan Pajangan, Kabupaten Bantul Yogyakarta ditinjau dari Morfologi dan Pati. Skripsi, Universitas Islam Negri Sunan Kalijaga Yogyakarta, 2015

Narayan, Ramadani. Biobased Biodegradable Products - An Assements. Michigan State University, Michigan. 2003.

Ningsing, SW. Operasi Pembuatan Bioplastik Polohidroksianoat Menggunakan Bakteri Mesofilik dan Media Limbah Cair Pabrik Kelapa Sawit. Tesis, Universitas Sumatra Utara, 2010

Nisa, U. Preparasi dan Karakterisasi Plastik Biodegradable dengan Penambahan Na-Pektin Kulit Pisang Sebagai Pembentuk Plastik dan Plasticizer Gliserol. Skripsi, Universitas Islam Negri Sunan Kalijaga Yogyakarta, 2012

Oktaviana, T. D. Pembuatan dan Analisa Film Bioplastik dari Kitosan Hasil Iradiasi Kitin yang Berasal dari Kulit Kepiting Bakau (Scylla serata). Skripsi, Universitas Pancasila Jakarta, 2002

Paramawati, R. Kajian Fisik dan Mekanik Terhadap Karakteristik Film Kemasan Organik dari Zein Jagung. Disertasi, Institus Pertanian Bogor, 2011

Richana, Nur.; \& Titi Chandra Sunarti. Karakterisasi Sifat Fisikokimia Tepung Umbi dan Tepung Pati Umbi Ganyong, Suweg, Ubikelapa, dan Gembili. Jurnal Pasca Panen. 2004, $1,29-37$
Romadloniyah, F. Pembuatan Dan Karakterisasi Plastik Biodegradable Dari Ongok Singkong Dengan Plasticizer Sorbitol. Skripsi, Universitas Islam Negri Sunan Kalijaga Yogyakarta, 2012

Sanusi, Ibrahim.; \& Maharam S. Teknik Laboratorium Kimia Organik, Graha Ilmu: Yogyakarta, 2013.

Sari, Eka.; Siti Syamsiah.; \& Sarto. Studi Biodegradasi Poli Hidroksi Butirat dalam Media Cair ((Biodegradation of Poly Hydroxy Butyrate in Liqaid Medium). jurnal Manusia dan Lingkungan. 2007, Vol. 14, No.3

Satrahamidjojo, H. Dasar Dasar Spekroskopi, Gajah Mada University Press: Yogyakarta, 2013.

Setiani, W.; Tety Sudiarti.; \& Lena Rahmidar. Preparasi Dan Karakterisasi Edible Film Dari Poliblend Pati Sukun-Kitosan. Jurnal Valensi. 2013, Vol. 3 No. 2

Saputra, A.; Mustofa, Lutfi.; \& E. Masruroh. Study Pembuatan dan Karakteristik Sifat Mekanik Plastik Biodegradable Berbahan Dasar Umbi Suweg (Amorphophallus campanulatus). Jurnal Keteknikan Pertanian Tropis dan Biosistem. 2015, Vol. 3 No 1

Sedyadi, E., Aini, S. K., Anggraini, D., Ekawati, D. P. 2016. StarchGlycerol Based Edible Film and Effect of Rosella (Hibiscus Sabdariffa Linn) Extract and Surimi Dumbo Catfish (Clarias gariepinus) Addition on Its Mechanical Properties. Biology, Medicine, \& Natural Product Chemistry. 5(2): 33-40

Tamela, P.; dan Lawerissa, S. Studi Pmebuatan tepung Lidah Buaya (Aloe vera L.). Skripsi, Universitas Sumatra Utara, 2008

Tongdeesoontorn W.; L.J. Maurer.; S. Wongroung.; P. S riburi.; dan P. Rachtanapun. Ef fect Carboxymethyl Cellulose Concentr asion on Phycal Properties of Biodegradable Cassava StrarchBased Film. Chemistry Central Jurnal. [online] 2011, 5:6. http.//jurnal chemistrycentral.com [diakses : 8 april 2015].

Ummah, Nathiqoh. Uji Ketahanan Biodegradable Plastic Berbasis Tepung Biji Durian (Durio Zibethinus Murr) Terhadap Air dan Pengukuran Densitasnya. Skripsi, Universitas Negeri Semarang, 2013

Utomo, Wahyu A.; Bambang Dwi A.; \& Muhammad Bagus H. Pengaruh Suhu Dan Lama Pengeringan Terhadap Karakteristik Fisikokimiawi Plastik Biodegradable Dari Komposit Pati Lifah Buaya (Aloe Vera)-Kitosan. Jurnal Bioproses Komoditas Tropis. 2013, Vol. 1 No. 1

Winarno, F.G. Kimia Pangan dan Gizi, PT. Gramedia Utama: Jakarta, 2002

Wirawan, Sang K.; Prasetya, Agus.; dan Ernie. Pengaruh Plasticizer pada Karakteristik Edible Film dari Pektin. Jurnal Reaktor. 2012, Vol. 14, No.

Whyman, K. Plastik dan Lingkungan. PT. Intan Sejati: Bandung, 2006

Yusmarlela. Study Pemanfaatan Plasticizer Gliserol dalam Film Ubi dengan Pengisi Serbuk Batang Ubi Kayu. Tesis, Universitas Sumatra Utara, Medan, 2009

Zulfa, Z. Pemanfaatan Pati Ubi Jalar untuk Pembuatan Biokomposit Semikonduktor. jurnal kimia UI. 2011.

Zulaidah, A. Peningkatan Nilai Guna Pati Alami Melalui Proses Modifikasi Pati. Jurnal Teknik kimia Universitas Pandanaran. 2013. 